\title{
Green Entrepreneurship and Employment Generation in a Developing Nation: The Nigerian Case
}

\author{
Musa Richard ${ }^{1}$, Fadeyi Olatunji ${ }^{2, *}$, Taiwo Samuel $^{1}$ \\ ${ }^{1}$ Department of Business Administration, D.S. Adegbenro ICT Polytechnic, Ogun State, Nigeria. \\ ${ }^{2}$ Department of Business Administration, Anchor University Lagos, Nigeria.
}

How to cite this paper: Musa Richard, Fadeyi Olatunji, Taiwo Samuel. (2021) Green Entrepreneurship and Employment Generation in a Developing Nation: The Nigerian Case. Journal of Humanities, Arts and Social Science, 5(1), 81-88.

DOI: $10.26855 /$ jhass.2021.01.009

Received: January 20, 2021

Accepted: February 22, 2021

Published: March 9, 2021

*Corresponding author: Fadeyi Olatunji, Department of Business Administration, Anchor University Lagos, Nigeria.

Email: fadeyiolatunji@yahoo.com

\begin{abstract}
This paper presents a link between green entrepreneurship and how it can drive employment in a developing economy - being an indicator for sustainable development through green production and services. It starts by introducing the concept of green entrepreneurship, and explains how difficult it has been to find a universal definition of the term. The study moved further to create a background for green business through methods that do not only combat climate change, but also provide lasting finances in the process. By adopting analysis of variance, standard deviation and mean, analyzed questionnaire instrument which sought to know the relevance and existing green entrepreneurship employments revealed that green entrepreneurship will ultimately add value to a nation's economy, and also bring it closer to reaching its Nationally Determined Contributions.
\end{abstract}

\section{Keywords}

Entrepreneurship, Green Entrepreneurship, Employment, Development, Green Innovation

\section{Introduction}

The earliest attempts aimed at finding a generalized definition for green entrepreneurship appeared around the 1990s. As reported by Hall (2016), "green entrepreneurship" was first mentioned by Gustav Berle (1991) in his book, "The Green Entrepreneur: Business Opportunities That Can Save the Earth and Make You Money". The author provided a poetic definition, explaining green entrepreneurship as the ability and willingness of humans to take up responsibilities of creating the kind of world they dream to live in. Farinelli et al. (2011) explained that models of green entrepreneurship are crucial to it definition, and are mainly based on the capacity of big firms to invest big on green marketing, instead of building green innovations.

From the forgone, it is obvious that developing a generalized definition for green entrepreneurship is a daunting task (O’Neill \& Gibbs, 2016). This is because the term was developed quite recently. Nevertheless, interest on green entrepreneurship is huge, and cuts across all works of life. This can be proved based on the number of green entrepreneurship ideas in extant literature, and the proliferation of the concept (Gibbs, 2006). In furtherance, there are quite a few words that can either be coined from green entrepreneurship, or possess the same meaning as the term. Figure 1 provides a summary of some of these words, and presents a new problem on the operationalization of the different concepts, and what should comprise green entrepreneurship, and what should the basic features of the concept be? 


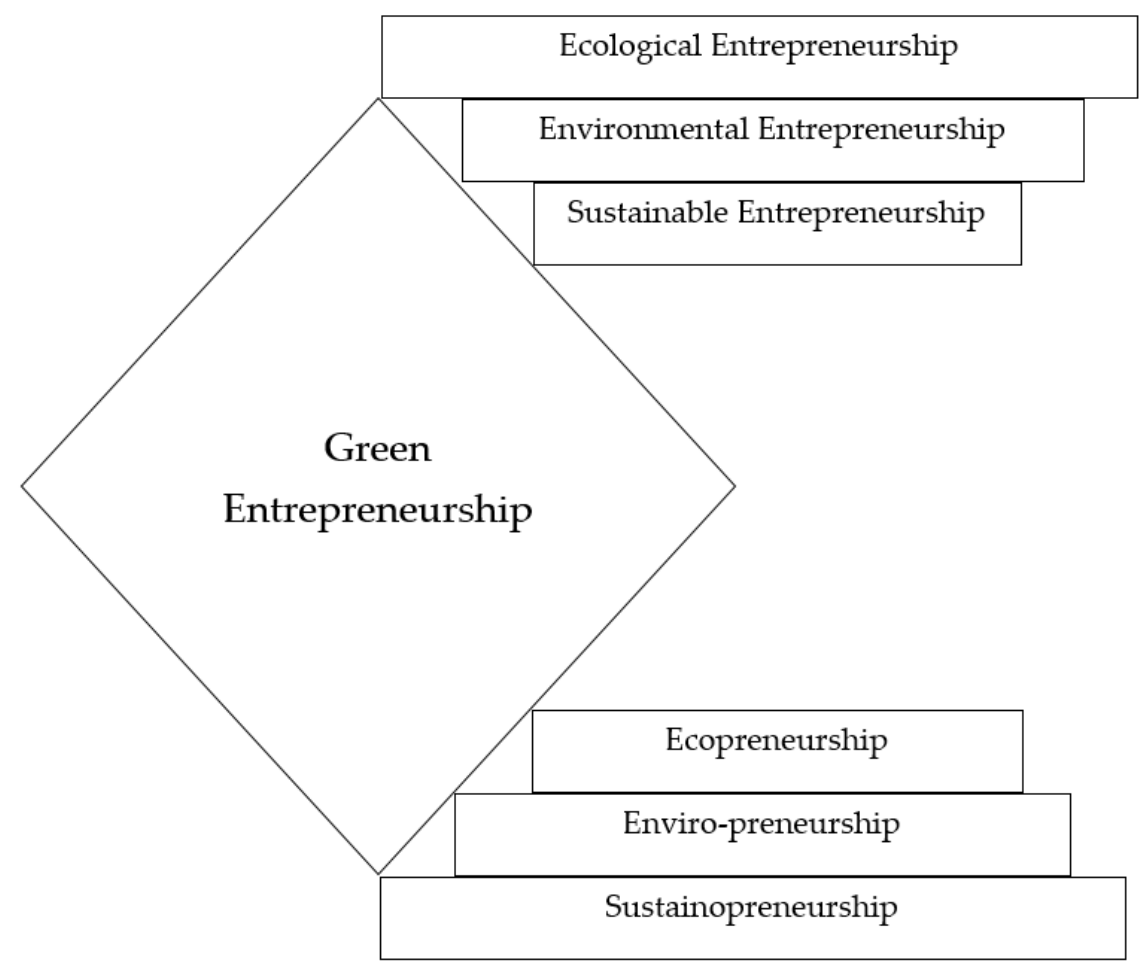

Figure 1. Some concepts that relate to green entrepreneurship.

Whilst the body of literature is yet to provide clear answers to some of these questions, we adopt the definition by Kirkwood and Walton (2014) who defined green entrepreneurship as activities that make purposeful efforts at proffering solutions to-, or curbing socio-environmental challenges using basic entrepreneurial ideas in a way that does not only benefit the environment, but also provide sustained financial gains for the entrepreneur. Similarly, anyone who sets-up and commences the running of an entrepreneurial entity with the goal of designing green products, or offering green service in an environmental friendly manner is referred to as a "green entrepreneur" (Schaper, 2016).

Given the utmost attention given nowadays to environmental-related issues both locally and at international level, mainstreaming greenness and ecological sustainability into employment and labor policies is fast becoming a popular event in societies around the world. This fusion provides better work-life and improved environmental agenda, so that socio-political ideologies are embedded within environmental issues in order to drive tremendous benefits. As a result, it is pertinent to mention the need to urgent develop policies that will help reach nationally derived contributions (NDCs) and implement the conditions stipulated within the Paris agenda (Matemilola et al., 2020). According to the International Labour Organization (ILO), there is a rich link between climate change, safe environments and employment. This is made clearer through the adoption of the so-called "green jobs" that are designed around green entrepreneurship (Fadeyi et al., 2019). In an address by the Director-General's on the ILO in the labor conference organized in 2007, for sustainable development goals to be actualized, it is important to acknowledge the impact of global warming and climate change on employment (Gibbs, 2006).

It is on this premise that the current study set out to examine how green entrepreneurship helps in the provision of employment in developing nation (Nigeria), viz-a-viz designing sustainability frameworks for such employment opportunities. To do this, this study is divided into five sections. The introductory section (Section 1) which deals with the definition of green entrepreneurship and links it with the work of the ILO in terms of employment. Section 2 briefly builds a literature background for green entrepreneurship by listing existing green entrepreneurial entities and describing what they do. In Section 3, attention is drawn to the method through which the goal of this study is attained, with specific reference to labour and employability. This section also details data gathering and analysis technique. Section 4 described data analysis and interpretation with the discussions derived therefrom. The section also makes an attempt to answer the research question. Finally, Section 5 describes future research directions in green entre- 
preneurship and its influence on employment, and draws relevant policy recommendations and conclusions.

\section{Research questions}

1) What kind of employment can green entrepreneurship provide?

2) How relevant are employment provided by green entrepreneurship ventures?

\section{Related literature}

Small and medium-sized enterprises (SMEs) have been identified as panacea to the economic growth of a nation (Hall, 2016). The implication is that countries that pay attention to SMEs, and try to provide a level playground for their development will surely reap the benefits. In contrast, nations that ignore SMEs often suffer slow-paced economic growth (Fadeyi \& Maresova, 2020). SMEs provide employment thus assisting in the growth of GDP growth (Fadeyi et al., 2019). Passionate entrepreneurs are ever-ready to take advantage of opportunities and possess skills that help them identify such regardless of the prevailing circumstances. As such, one of the many advantages that comes with small enterprises is innovation that takes the nation close to achieving sustainable development goals (Matemilola \& Fadeyi, 2020).

Entrepreneurs involved in green businesses are able to make provisions that initiate and lead the so-called green economy through completely green services as well as products (Bruin, 2016). This can be achieved through sustainable production methods which leads to an increased demands for these products and services, and to green job creation (Kirkwood \& Walton, 2014). In this context, green entrepreneurship can be seen from two unique viewpoints. The first is in relation to what the green entrepreneurship business has as its output; be it a product or a service, while the other is the procedure through which the production of service activity is executed (Allen \& Malin, 2008). Green entrepreneurs can get into a completely green sector and continue to provide either of these in an environmental friendly manner. As an alternative, they can make efforts to provide such services using other clean technologies. All these aspects are crucial for the green business value-chain to create additional employment at every point in time, while cutting down impacts of the usual conventional processes to production and service rendering.

Overall, it is very important for developing nations to encourage green businesses through varying funding interventions at all levels (Nikolaou et al., 2011). This way, green businesses are nurtured, and the green culture is protected. Part of the encouragement that green entrepreneurship can have to better impact employment rates is the provision of green entrepreneurship training packages. These trainings draw out the skills of each individual, in relation to a wide variety of available green businesses. According to the UN Habitat (2017), green entrepreneurship trainings also equips interested young person with all the required knowledge in the green business value chain and gives them the opportunity to be a part of the solution to existing environmental challenges, through green business ownership. An important consideration in the push for green entrepreneurship is public perception towards green services and products. This can either make or mar the development of green entrepreneurship. As a result, setting up effective a policy framework for green entrepreneurship through regulation can spur huge investments in green business ideas. Part of this regulatory framework could be the easy registration of green business, and the creation of laws specific to stimulating growth in green entrepreneurship, which are relatively rare in many developing nations, where the signals for environmental incentive are often revealed via environmental policies that become business ideas. As a result, carrying out an assessment for sustainable green entrepreneurial ventures can help identify priority intervention areas that are in alignment with policy initiatives and legal regulations between different ministries and sectors (Matemilola \& Fadeyi, 2020). This will also help to identify areas within the green business value chain that could possibly yield good returns on investment, as well as financial or tax incentives in public green procurement processes which may be useful for can green start-ups, thus yielding greater employment opportunities.

As reported by Affolderbach \& Krueger (2017), capacity building and the availability of funding for green entrepreneurs is crucial for small green business to be able to provide employment to a growing population. When green business receive the right funding incentives, they are better equipped to be able to teach green-related skills related to the use of alternative energy sources among other things (Nikolaou et al., 2011). Similarly, when green business are provided with an enabling environment which helps them to improve and expand their activities in specific sectors and nurtures innovation in management, these business, just like conventional business surpass challenges and move at a greater pace, thus becoming huge employers of labor. The ILO for instance has a number of support tools specially designed for green business start-ups via the so-called "Start and Improve Your Business" programme. The organization also specifically has training packages that are directed at the challenges of green entrepreneurship business like waste handling and management (Galkina \& Hultman, 2016). 
Whilst some green business may be more strategic and better funded than others, it is important that green business link up for optimum performance (Galkina \& Hultman, 2016). For instance, a recycling company would most likely need the services of a waste handling firm. Although each has a unique role in the entire value-chain, a fusion of these firms will create better performance and faster achievement of results. What this imply is that partnerships are indeed of necessity, if green business will remain competitive and achieving sustainable growth at the same time (Karimi \& Chashmi, 2019). As a result, one role that governments in developing nations need to play is to encourage green entrepreneurs identify and link up with related market opportunities, in other to strengthen individual prospects that can allow optimum benefits from economic viewpoint while also entrenching environmental considerations within the value chain.

\section{Green Entrepreneurship in Nigeria and its Impact on Employment}

The green business environment in Nigeria is moving at a very rapid rate. This can be seen in the number of green entrepreneurship business coming up. Recently, the National Power Training Institute of Nigeria (NAPTIN) partnered with a tech-based firm for the proposed development of a green innovation hub with the single goal of driving green business development within the Nigerian energy sector, while also improving relationship between public and private organizations (UN Habitat, 2017). The green innovation hub will massively improve the skills of green entrepreneurs, who will in turn use these skills to improve the countries' employment rating. The entire green business scene in Nigeria is further boosted by the N10.6 billion green bonds to aid renewable energy projects to protect the environment (Fadeyi \& Maresova, 2020). This is geared towards the accomplishment of the Paris Agreement goals (Matemilola \& Fadeyi, 2020). Green Bonds are like regular bonds, but with a slight difference- they can only be used to fund projects that have been identified to have environmental benefits, with their contribution to emissions reduction clearly articulated.

Oyekanmi (2020) reported a sudden increase in the number of unemployed persons in Nigeria from $23.1 \%$ in 2018 to $27.1 \%$ this year. The implication is that more than half of Nigeria's should-be working population aged 15-64 years are either unemployed or under-employed. From all indication, the country needs to embrace all forms of methods through which these figures can be reduced. One way to do this is to embrace green entrepreneurship, especially as the national has a population that countinues to generate huge amount of waste. As such, investment should be directed towards cleaner production and waste-to-wealth efforts.

\section{Method and Analysis}

This study adopts descriptive survey design. It is conducted across six Nigerian states; Edo (4221), Ondo (2231), Ekiti (3879), Ogun (4534), Osun (3799), and Lagos (5321), most of which are located in the South-western part of the country. Total study population from the sum of population from each state is 23,985 who are individuals looking to secure employment. A multistage sampling was used, so that at initial stage, a population stratification was done. This is followed by the use of the so-called TaroYamene sample size calculation to arrive at 393 respondents for the study. Furthermore, another sampling method was carried out in form of proportionate sampling to get 363 green entrepreneurship business across the six states. Next, we used convenience sampling to get respondents. This was important for as it is impossible to go round all green business in the six states. A structured questionnaire; "Green Entrepreneurship Impression for Employment" comprising of 20 items (10 for each research question) was used. The questionnaire had options Strongly Agree (SA), Agree (A), Disagree (D), and Strongly Disagree (SD), and denoted as 4, 3, 2, and 1 Likert scale structure. Face validation was done by 15 experts five, together with reliability testing. Data analysis was done using Cronbach Alpha. Reliability of questionnaire through a pilot survey resulted in 0.88 coefficient, good enough to assume internal consistency of variables, and fit for use.

Data analysis was carried out with calculation of ANOVA, mean, and standard deviation. We used the calculation from the mean to answer the research questions, while standard deviation was adopted to show how other questionnaire choices move away from the mean. For decision on any one research item, mean of $>2.50$ was accepted, while a score $<$ the mean value was not accepted. ANOVA was adopted for hypotheses testing at 0.05 significance.

\section{Results}

Research question 1: What kind of employment can green entrepreneurship provide?

Table 1 shows item statements on the questionnaire related to the first research question. From the table, $\mathrm{X}$ represents Mean, SD is Standard Deviation, A represents Agreed. Analysis on the average respondents' rating related 
to the employment that green entrepreneurship can generate showed that items varied between 3.17 and 3.24. This is more than 2.50 which is the specified cut-off. As such, all the items are suited as green entrepreneurship jobs. Furthermore, SD was mostly found to be between 0.76 and 0.89 . These values are below 1.96, implying relative closeness to the mean and providing more reliability.

Table 1. Standard deviation and mean rating of the kinds of employment that green entrepreneurship can generate

\begin{tabular}{|c|c|c|c|c|}
\hline $\mathbf{S} / \mathbf{N}$ & Item statements & $\mathbf{X}$ & SD & Remark \\
\hline 1. & Individuals/firms that design biodegradable products & 3.24 & 0.84 & A \\
\hline 2. & Waste handling/handling entrepreneurs & 3.22 & 0.76 & A \\
\hline 3. & Wind farm managers & 3.21 & 0.83 & A \\
\hline 4. & Natural environment conservation agents & 3.27 & 0.82 & A \\
\hline 5. & Climate change social media persons who disseminate information & 3.17 & 0.84 & A \\
\hline 6. & Climate smart farmers & 3.20 & 0.84 & A \\
\hline 7. & Solar panel designers & 3.18 & 0.83 & A \\
\hline 8. & Individuals that research into clean energy & 3.17 & 0.87 & A \\
\hline 9. & Entrepreneurship businesses that manufacture useful items from plastic & 3.22 & 0.89 & A \\
\hline 10. & Entrepreneurs that re-design used and yet-to-be discarded items into useful products (waste-to-wealth) & 3.21 & 0.85 & A \\
\hline
\end{tabular}

From the first research question, we can develop a null hypothesis as stated below.

Hypothesis 1. Green entrepreneurship does not significantly drive any kind of employment generation.

This statement can is tested using ANOVA stated on Table 2.

Table 2. ANOVA comparing responses of individuals relating green entrepreneurship with employment generation

\begin{tabular}{cccccc}
\hline Source of diff & Sum of square & Df & Mean Square & F & Sig \\
\hline Between groups & 0.215 & 3 & 0.05 & 0.44 & 0.03 \\
Within groups & 71.62 & 388 & 0.1 & & \\
Total & 71.83 & 391 & & \\
\hline
\end{tabular}

From Table 2, F-value of 0.44 and a P-value of 0.03 at $392 \mathrm{df}$ is less than 0.05 . This implies that green entrepreneurship significantly drives the generation of employment in Nigeria. As such, the null hypothesis is rejected as we have a cause to believe that employment can be generated from green entrepreneurship.

Research question 2: How relevant are employment provided by green entrepreneurship ventures?

Table 3. Standard deviation and mean rating of the relevance of green entrepreneurial ventures

\begin{tabular}{|c|c|c|c|c|}
\hline $\mathbf{S} / \mathbf{N}$ & Item statements & $\mathbf{X}$ & SD & Remark \\
\hline 11. & Contributes to Nigeria's GDP & 3.28 & 0.80 & A \\
\hline 12. & Acts as a means of livelihood for many individuals & 3.48 & 0.74 & A \\
\hline 13. & Protects the environment against the effect of climate change & 3.45 & 0.77 & A \\
\hline 14. & Preserves health and well-being of the population & 3.40 & 0.79 & A \\
\hline 15. & Reduces the possibilities of outbreak of diseases & 3.37 & 0.70 & A \\
\hline 16. & Contributions to the steps towards millennium development goals & 3.35 & 0.67 & A \\
\hline 17. & Contributions to the achievement of sustainable development goals & 3.30 & 0.73 & A \\
\hline 18. & Adds to existing growth related to Nationally Determined Contributions & 3.29 & 0.74 & A \\
\hline 19. & Improves country's carbon rating & 3.27 & 0.65 & A \\
\hline 20. & Creates better environmental awareness & 3.31 & 0.71 & A \\
\hline
\end{tabular}

In terms of the relevance of employment provided by green entrepreneurship as shown, analysis on Table 2 reveals rating between 3.27 and 3.48. These figures are much higher when compared to the 2.50 cut-off, implying that is questionnaire items on green entrepreneurship employment opportunities are indeed useful. Table 3 also shows SD 
between 0.64 and 0.80 . Since these values are low in comparison to 1.96 , it can be assumed that respondents' suggestions do not significantly differ from the mean. This makes the means some worth reliable.

From the second research question, we can develop a null hypothesis as stated below.

Hypothesis 2. Green entrepreneurship employments are not significantly relevant to Nigerian economy.

The above hypothesis can be tested as shown in Table 4 .

Table 4. ANOVA comparing responses of individuals relating relevance of green entrepreneurship employments to Nigeria

\begin{tabular}{cccccc}
\hline Source of diff & Sum of square & Df & Mean Square & F & 0.29 \\
Between groups & 0.120 & 3 & 0.30 & 0.01 \\
Within groups & 72.43 & 388 & 0.1 & \\
Total & 72.55 & 391 & & \\
\hline
\end{tabular}

From Table 4, F-value of 0.29 and a P-value of 0.01 at $392 \mathrm{df}$ is less than 0.05 . This implies that green entrepreneurship employments are significantly relevant to Nigerian economy. As such, the null hypothesis is rejected as we have a cause to believe that employment around green entrepreneurship is relevant to Nigeria's economy.

\section{Discussions}

Findings from this study revealed the link between green entrepreneurship and employment. By adopting environmental friendly businesses through clean production, as well as services (e.g. waste management and handling), there is a likely reduction in the damage cause to ecology, while also ensuring sustainable development. In terms of the relevance of the respondents opined that the advent of green businesses could have a positive impact on the nation's Gross Domestic Product (GDP). This is because green entrepreneurship provides international funding opportunities for business that protect the environment. According to Fadeyi and Maresova (2020), many countries in Africa greatly rely on importation of renewable/recyclable products. Nevertheless, these products can as well be produced in Nigeria, if the green entrepreneurs are rightly motivated. In contrast, when clean sources of production are ignored, there is bound to be an increase in atmospheric carbon concentration, which in turn leads to the release of some forms aero-allergenic substances that harms the health of the populace. The study further found that enhancing green entrepreneurship business with encouragement from consumer, implies that awareness is gradually being created for green products that are able to meet customer needs.

With regards to its relevance, green entrepreneurship could be a source of livelihood for many unemployed persons today. For instance in Lagos state which is regarded as one of the most populated cities in the world, per capita waste generation is given as of $0.5 \mathrm{~kg}$ per day, so that the entire Lagos produces approximately 10,000 tons of urban waste daily (Bakare, 2020). It will take at least 1,000 additional hands to be able to efficiently handle this waste and manufacture other useful materials therefrom. Although the Lagos Waste Management Authority is doing a good job. It lacks sufficient manpower to turn the entire waste generated in Lagos to wealth. Another relevance of green entrepreneurial employment is the fact that it continue to drive the country toward the sustainable development goals. Goal 6 emphasizes the need for societies to improve on clean water and sanitation, and the easiest way to reach this is by allowing green entrepreneurship to thrive. With green entrepreneurship also comes the production of clean energy sources such as solar and wind power, which are gradually been appreciated in Nigeria today.

Being a signatory to the Paris Agreement, Nigeria is under the obligation to make known her post-2020 climate action plans to the United Nations. Without a significant push toward green entrepreneurship, it would be difficult to have any feasible plans in place. Nationally determined contributions (NDCs) are the pillars upon which the Paris Agreement rest in the planning of efforts to cut emissions. The implication is that green entrepreneurship is bound to help Nigeria in reaching her NDCs. In general, this study in consonance with the work of Muo and Adebayo (2019), who proposed the need for Nigeria to fully encourage green entrepreneurship among youth, so that the country can actualize the dreams of the sustainable development agenda. It is also in line with the opinions of Anabaraonye, Chukwuman, and Eriobu (2019), who suggested the need for more awareness for green entrepreneurship and green businesses through creative writing.

\section{Conclusions}

This paper has so far emphasized the need to allow green entrepreneurship thrive. This is mainly because, the rate of unemployment in Nigeria is alarming and many young people are living in frustration. Interestingly, all avenues to 
combat the scourge of unemployment must be combatted. One way to do so is to embrace green entrepreneurship who raw materials in most cases are everyday items seem within the environment. Given the forgone analysis and explanation, the following recommendations are suggested.

1) Nigeria should as a matter of urgency provide more incentives to green entrepreneurship practitioners so that they can contribute more to society;

2) Unemployed youth should be opened to learning how they can be a part of the green revolution.

\section{References}

Affolderbach, J., \& Krueger, R. (2017). "Just” ecopreneurs: Re-conceptualising green transitions and entrepreneurship. Local Environment, 22(4), 410-423. https://doi.org/10.1080/13549839.2016.1210591.

Allen, J. C., \& Malin, S. (2008). Green Entrepreneurship: A Method for Managing Natural Resources? Society \& Natural Resources, 21(9), 828-844. https://doi.org/10.1080/08941920701612917.

Anabaraonye, B., Chukwuma, O. J., \& Eriobu, C. M. (2019). Green Entrepreneurial Opportunities in Climate Change Adaptation and Mitigation for Sustainable Development in Nigeria. Journal Od Environmental and Pollution Management, 2(102), 1-6.

Bakare, W. (2020, February 11). Solid Waste Management in Nigeria. https://www.bioenergyconsult.com/solidwaste-nigeria/.

Bruin, A. de. (2016). Towards a framework for understanding transitional green entrepreneurship. Small Enterprise Research, 23(1), 10-21. https://doi.org/10.1080/13215906.2016.1188715.

Fadeyi, O., \& Maresova, P. (2020). Stakeholders' Perception of Climate Actions in Some Developing Economies. Climate, 8(6), 66. https://doi.org/10.3390/cli8060066.

Fadeyi, O., Maresova, P., Stemberkova, R., Afolayan, M., \& Adeoye, F. (2019). Perspectives of University-Industry Technology Transfer in African Emerging Economies: Evaluating the Nigerian Scenario via a Data Envelopment Approach. Social Sciences, 8(10), 286. https://doi.org/10.3390/socsci8100286.

Galkina, T., \& Hultman, M. (2016). Ecopreneurship-Assessing the field and outlining the research potential. Small Enterprise Research, 23(1), 58-72. https://doi.org/10.1080/13215906.2016.1188716.

Gibbs, D. (2006). Sustainability Entrepreneurs, Ecopreneurs and the Development of a Sustainable Economy. Greener Management International, 2006(55), 63-78. https://doi.org/10.9774/GLEAF.3062.2006.au.00007.

Hall, R. (2016). The Enterprising Eco-villager: Achieving Community Development through Innovative Green Entrepreneurship. Baltic Eco. www.balticecovillage.eu.

Karimi, R. F., \& Chashmi, S. A. N. (2019). Designing Green Entrepreneurship Model in Sustainable Development Consistent with the Performance of Tehran Industrial Towns. Journal of Business-to-Business Marketing, 26(1), 95-102. https://doi.org/10.1080/1051712X.2019.1565143.

Kirkwood, J., \& Walton, S. (2014). How green is green? Ecopreneurs balancing environmental concerns and business goals. Australasian Journal of Environmental Management, 21(1), 37-51. https://doi.org/10.1080/14486563. 2014.880384.

Matemilola, S., \& Fadeyi, O. (2020). Bamako Convention. In S. Idowu, R. Schmidpeter, N. Capaldi, L. Zu, M. Del Baldo, \& R. Abreu (Eds.), Encyclopedia of Sustainable Management (pp. 1-5). Springer International Publishing. https://doi.org/10.1007/978-3-030-02006-4_522-1.

Matemilola, S., Fadeyi, O., \& Sijuade, T. (2020). Paris Agreement. In S. Idowu, R. Schmidpeter, N. Capaldi, L. Zu, M. Del Baldo, \& R. Abreu (Eds.), Encyclopedia of Sustainable Management (pp. 1-5). Springer International Publishing. https://doi.org/10.1007/978-3-030-02006-4_516-1.

Muo, I., \& Adebayo Azeez, A. (2019). Green Entrepreneurship: Literature Review and Agenda for Future Research. International Journal of Entrepreneurial Knowledge, 7(2), 17-29.

Nikolaou, E. I., Ierapetritis, D., \& Tsagarakis, K. P. (2011). An evaluation of the prospects of green entrepreneurship development using a SWOT analysis. International Journal of Sustainable Development \& World Ecology, 18(1), 1-16. https://doi.org/10.1080/13504509.2011.543565.

O’Neill, K., \& Gibbs, D. (2016). Rethinking green entrepreneurship_Fluid narratives of the green economy: Environment and Planning A: Economy and Space. https://oi.org/10.1177/0308518X16650453.

Oyekanmi, S. (2020, August 14). Nigeria's unemployment rate jumps to $27.1 \%$ as at 2020 Q2. Nairametrics. 
https://nairametrics.com/2020/08/14/breaking-nigeria-unemployment-rate-jumps-to-27-1/.

Schaper, M. (2016). Understanding the green entrepreneur. In Making Ecopreneurs: Developing Sustainable Entrepreneurship (p. 14). Gower Publishing Limited. https://doi.org/10.4324/9781315593302-7.

UN Habitat. (2017, February 10). Youths in Nigeria trained in renewable energy technologies and green entrepreneurship. Africa Renewal. https://www.un.org/africarenewal/news/youths-nigeria-trained-renewable-energy -technologies-and-green-entrepreneurship. 